KAWISTARA

VOLUME 4

No. 2, 17 Agustus 2014

Halaman 111-224

\title{
POLITIK SELEBRITAS ELABORASI TEORITIK TERHADAP MODEL KAMPANYE BARU
}

\author{
Wasisto Raharjo Jati \\ Pusat Penelitian Politik-Lembaga Ilmu Pengetahuan Indonesia \\ Email: wasisto.raharjo.jati@gmail.com
}

\begin{abstract}
The discussion about concept of celebrity politics is a new study in the social sciences and political landscape in the new Indonesian electoral democracy post-1999. Phenomenon of celebrity into the realm of practical politics itself actually comes as a vote getter nature every political campaign. The existence of massive publicity in the media as well as a performance appears to attract public sympathy. However, the pattern of these celebrities also performed by politicians to show any aspect of their daily life to become material for public consumption. The implication is that creating any sympathy and empathy from the public to candidate or party. Political journalism plays a major role in creating both the presence of the news by creating better and vice versa, creating a presence of construction to candidates or parties. This paper will elaborate more on this celebrity political perspective.
\end{abstract}

Keywords: Celebrity Politic, Endorser, Voting Getter, Political Strategy.

\begin{abstract}
ABSTRAK
Pembahasan mengenai konsep celebrity politic merupakan kajian baru dalam lanskap ilmu sosial dan politik di Indonesia yang baru mengimplementasikan demokrasi elektoral paska 1999. Fenomena selebriti yang masuk ke dalam ranah politik praktis sendiri sejatinya hadir sebagai vote getter alam setiap kampanye politik. Adanya publikasi di media yang masif maupun peforma yang acap kali ditampilkan membuat sosok selebriti menjadi daya magnet untuk menarik simpati publik. Hal itu yang kemudian berkausalitas dengan munculnya faktor endorsement suara yang akan diperoleh pada pemilu nanti. Akan tetapi, pola selebritas tersebut juga dilakukan oleh politisi untuk menampilkan adanya aspek aspek kesehariannya untuk menjadi bahan konsumsi publik. Implikasinya adalah menciptakan adanya simpati dan empati dari publik kepada kandidasi maupun partai. Adapun jurnalisme politik berperan besar dalam menciptakan kedua hal tersebut dengan menciptakan adanya pemberitaan lebih baik maupun sebaliknya, menciptakan adanya konstruksi kepada kandidat maupun partai. Tulisan ini akan mengelaborasi lebih lanjut mengenai perspektif politik selebritas ini.
\end{abstract}

Kata Kunci: Selebriti Politik, Endorser, Voting Getter, Strategi Politik 


\section{PENGANTAR}

Pembacaan atas konstelasi demokrasi di Indonesia sangatlah dinamis paska tahun 1999. Pertumbuhan partai politik yang begitu masif seiring dengan diimplementasikannya sistem multipartai. Minat publik yang tinggi semasa awal pelaksanaan pemilu 1999 dengan mencatat prosentase aktif memilih mencapai 92,5 persen. Kesadaran warga negara untuk ikut berpolitik praktis juga ditujukan untuk mengubah tatanan negara menjadi lebih baik paska rezim otoritarian. Adanya ragam cerita mengenai demokrasi tersebut mengindikaskan bahwa pemilu sudah diterima sebagai mekanisme dalam setiap rezim pemerintahan baik dalam ranah eksekutif maupun legislatif. Adapun dalam penyelenggaraan pemilu hingga 2014 ini, kesadaran publik untuk mengikuti proses elektoral semakin rasional. Makna rasional sendiri dapat dianalisis dalam sebuah premis, yaitu ketika rasionalitas politik semakin tinggi berbanding lurus dengan menurunnya tingkat partisipasi publik dalam elektoral. Publik mengalami pergeseran transendetal dalam memaknai kampanye. Kampanye bukan lagi dimaknai secara ideologis yang hanya menampilkan pesan abstrak dan utopis. Akan tetapi, lebih mengarah kepada aksi nyata dan tindakan riil. Adanya pergeseran dalam kampanye inilah yang kemudian menciptakan adanya politik pencitraan yang dilakukan oleh politisi maupun partai politik. Politik pencitraan menjadi jamak dilakukan seiring dengan berkembangnya media, teknologi, maupun informasi untuk mendapatkan simpati publik secara instan dan masif.

Tahun 2004 merupakan bentuk transisi tersebut di mana model kampanye sendiri tidak digerakkan secara konvensional klasik seperti halnya orasi massa di lapangan terbuka, pawai kendaraan dengan atribut partai, maupun acara pembagian bantuan sosial kepada masyarakat. Pada tahun tersebut mengindikasikan adanya tahun televisi di mana publisitas dalam lingkup ruang media lebih mengena di hati dan pikiran pemilih, daripada harus bercapai, berpanas, maupun berpeluh demi hanya mengikuti pesan-pesan kampanye politik yang serba abstraktif. Artinya bahwa terjadi perubahan dalam membingkai kampanye sebagai komoditas politik yang serba kaku dalam komunikasinya, tetapi sebagai komoditi hiburan yang mampu mengikat publik. Adapun jargon politik yang serba sloganitik, agitatif, bahkan normatif divisualisasikan sebagai hiburan yang mampu untuk menarik untuk dilihat, dirasakan, dan diterima pendapatnya. Maka dari itu, konteks jurnalisme politik berlaku, manakala media dan politik kemudian bersinggungan dalam kampanye politik. Pesan komunikator kepada audiens akan secara cepat terdesiminasikan melalui kampanye di media. Figur kemudian berkembang menjadi sosok penting untuk dikomoditaskan dalam kampanye politik. Hegemoni media yang masif dalam segala lini kehidupan dengan perkembangan informasi yang cepat dan berkembang secara tidak langsung telah menyesuaikan prokem bahasa politik menjadi bahasa populis yang lebih diterima. Dimensi politik persuasif melalui kampanyemediaakan menghadirkan adanya snow ball effect bagi kandidat karena efeknya yang langsung menjalar ke berbagai jaringan masyarakat. Oleh karena itulah, opini publik untuk menaikkan elektabilitas sendiri lebih efektif dan efisien melalui kampanye. Media akan menimbulkan gejala media darling di mana media akan melakukan framing yang dapat meyakinkan publik sehingga berimplikasi pada social darling. Fenomena social darling itulah yang berlinier dengan elektabilitas kandidat maupun partai. Untuk itu, pembentukan darling sebagai akumulator suara menjadi penting dibicarakan dalam konteks ini, yaitu (1) darling sebagai bentuk strategi dalam meraih suara sebanyak mungkin, (2) darling sebagai bentuk figur / agensi yang berperan dalam mendapatkan suara dalam kampanye.

Terkait mengenai dengan strategi, darling ini dapat dianalogikan sebagai cara untuk mempopulerkan diri baik secara artifisial maupun riil di depan publik agar 
dapat tercitrakan dan terimajinasikan sebagai sosok yang terkenal dan peduli dengan publik. Model strategis ini biasanya digunakan untuk pengkultusan figur secara temporer selama masa kampanye dan kemungkinan besar tidak berlanjut lagi pada setelah kampanye. Model strategi ini biasanya diwujudkan dalam pemberian bantuan materi yang sifatnya langsung dan mengena sehingga simpati publik secara instan dapat diraih.

Terkait dengan darling sebagai sosok figur yang menjadi lokus sentral dalam kampanye politik di media demi mendapatkan akumulasi suara yang banyak. Pemaknaan sebagai sosok figur dalam hal ini lebih mengarahkan kepada pembentukan agensi atau intermediary yang menjembatani antara politisi/partai dengan publik. Maka dari itu, sosok selebriti sebagai tokoh publik tentu tidak dapat dinafikan begitu saja. Selebriti yang selama ini selalu muncul dalam ekspose dalam pemberitaan media massa baik cetak dan elektronik sendiri adalah figur yang selalu dinanti publik baik dalam penampilan maupun sisi-sisi kehidupannya. Semakin berprestasi, terkenal maupun kontroversi, figur selebriti akan senantiasa dicari dan digandrungi oleh publik untuk melihat perkembangannya dari waktu ke waktu. Pemaknaannya adalah selebriti adalah figur biopolitik yang menjalankan fungsi-fungsi politik secara tidak langsung sehingga mampu menarik perhatian lebih. Tubuh selebriti diibaratkan adalah tubuh yang dikeremuni oleh publik sehingga setiap jengkal kehidupannya akan segera diketahui publik. Dari situlah kemudian popularitas untuk mendapatkan massa kemudian diperlihatkan dan diperhatikan secara saksama.

Pada dunia politik praktis, sosok selebriti adalah sosok yang seksi untuk digali lebih jauh potensinya dalam meraih suara. Hal itulah yang menjadikan selebriti sendiri menjadi tubuh yang diperebutkan oleh kandidat maupun partai dalam meraih elektabilitas tinggi melalui massa yang dihadirkan selebritis tersebut. Akan tetapi, cara sedemikian tidak sahih sepenuhnya dalam model kampanye politik. Kandidat juga menggunakan cara-cara selebritas dalam berkampanye maupun berpolitik agar mampu mengubah dan menghadirkan dimensi politik praktis yang serba kolutif maupun koruptif menjadi lebih humanis agar lebih dapat diterima masyarakat dengan melakukan pencitraan baik individu maupun kelompok. Berkembangnya media dan kecepatan informasi ditambah pula selebritas sebagai dirigen merupakan nuansa baru dalam memaknai kampanye politik dalam demokrasi elektoral Indonesia paska 2004. Hal yang urgen dan signifikan untuk digali lebih lanjut adalah seberapa efektif dan efisienkah model selebritas politik maupun politik selebritas dalam upayanya meraih dukungan suara besar? Apa saja kekurangan dan kelebihannya daripada model tersebut? Tulisan ini akan mengelaborasi lebih lanjut mengenai selebritas politik maupun politik selebritas dalam perannya sebagi voting getter dalam model kampanye politik di Indonesia.

Metode penelitian yang digunakan dalam riset ini adalah metode kepustakaan (library research). Pertama, analisis data dalam penelitian ini dilakukan dengan cara mengumpulkan berbagai macam sumber literature terkait yang relevan misalnya buku, jurnal ilmiah, prosiding, maupun artikel ilmiah lainnya yang relevan dalam penelitian (Zed, 2004: 34). Kedua, setelah semua dikumpulkan, kemudian penelitian melakukan klasifikasi data dengan cara coding untuk menemukan urgensi data yang perlu diolah terlebih dahulu baru kemudian dirangkai dengan data komplementer lainnya. Ketiga, kemudian merangkai data utama dengan dengan data komplementer tersebut sehingga dapat disusun dalam suatu naskah akademik yang padu.

\section{PEMBAHASAN}

Kajian mengenai preferensi politik Indonesia dapat dianalisis mengenai dua premis penting, yaitu patrimonialisme dengan figurisme. Meskipun boleh dikata rasionalitas semakin tinggi, tetapi manakala 
menemui figur yang dipersepsikan sebagai figur yang transformatif maupun reformis. Maka preferensi publik akan mengalami gejala social proofing, yaitu gejala preferensi massal yang mengarahkan dukungan kepada satu figur tertentu. Maka untuk menciptakan dan mengkonstruksi preferensi politik itulah kemudian upaya klarifikasi menjadi penting untuk mendapatkan rekognisi maupun afeksi dari publik. Glorifikasi di sini dimaknai sebagai bentuk upaya menampilkan diri maupun kolektif secara berlebih atau menghebohkan sesuatu hal agar mendapatkan perhatian banyak. Hal itulah selaras dengan tesisnya Geertz tentang negara teater. Negara teater sendiri menerjemahkan kuasa, relasi kuasa, maupun preferensi politik dibentuk dan dikonstruk dalam sebuah seremoni-formalistik. Hal pertama yang perlu dimengerti adanya mengenai teater secara semiotik adalah kesenjangan antara realita dengan utopia. Politik dalam negara teater dalam berada dalam di irisan antara realita dan utopia. Hal itu kemudian diwujudkan dalam bentuk rekayasa politik yang diorganisir. Pada akhirnya kemudian terjadi adalah politik topeng di mana realita kemudian dibungkus dalam bentuk utopia kebaikan. Dalam hal romantisme maupun heroisme menjadi bagian lain dari konstruksi darling tersebut yang ingin menampilkan sebuah sosok yang dikenal dan dipuja publik. Model kampanye politik di Indonesia, aib kemudian diteaterkan dalam bentuk seremonialkan berbagai bentuk perilaku populis, atraktif, maupun realis. Dari situlah kemudian konteks darling kemudian dibentuk sebagai personifikasi figur atau kolektif.

Pengertian teater sendiri merujuk pada kebesaran sebuah pertunjukkan maupun atraksi budaya yang mampu mengafeksi publik. Adapun negara teater sendiri mengartikan diri sebagai bentuk politik hiperbola yang menempatkan figur ataupun kolektif menjadi sosok yang pesohor dan kharismatik. Pada lanskap sosiologis masyarakat di Indonesia, kecenderungan untuk memamerkan diri guna menuai simpati, dan menarik perhatian masih menjadi pola baku. Budaya pamer tersebut selaras dengan upaya pemenuhan batin seseorang untuk mendapat rekognisi maupun afeksi dari orang lain. Kaitannya dengan pembentukan darling maupun juga selebri-politik sendiri dapat dianalisis sebagai bentuk pola relasi yang simetris. Secara etimologis, selebriti adalah figur sentral yang berperan sebagai penarik simpatidanempati publik agar selalu terpusat kepada dirinya. Dari situlah kemudian, pemusatan terhadap figur maupun kolektif itulah yang kemudian menciptakan adanya persepsi darling. Makna darling dalam hal ini dapat dimaknai sebagai bentuk perhatian lebih yang dialamatkan publik kepada figur tertentu. Oleh karena itulah, dalam taraf ini, selebriti menjadi penting untuk dikonteskan sebagai penarik simpati publik tersebut melalui berbagai macam metode yang dilakukan. Adapun metode yang jamak dilakukan adalah melalui media.

Membaca relasi selebriti sebagai darling dengan politik, sekiranya perlu terlebih dahulu tentang konstelasi media dengan politik. Kedua hal tersebut menjadi penting untuk dipahami mengingat selebriti sendiri merupakan sebentuk aktor intermediari yang menjembatani kampanye politik dalam ruang media. Dalam hal ini, terdapat dua praksis utama, yaitu politicisied media dan juga media politicisied. Pertama, yaitu politicisied media mengandung arti bahwa independensi media selaku lembaga informasi sendiri sudah terkooptasi oleh banyaknya kepentingan politik yang bermain dalam pemberitaan. Jurnalisme kemudian direcoki dan diintervensi oleh pelbagai kepentingan politik. Kedua, yaitu media politicisied mengandung arti bahwa media justru memainkan peranan penting dalam memainkan bidak-bidak politik yang hendak dilakukanoleh paraaktor. Media berkembang menjadi political steering yang sangat efektif maupun efisien dalam mempengaruhi jalannya politik. Peran selebriti sangatlah penting dalam menjambatani kedua entitas tersebut dengan menjadikan dirinya sebagai endorser. Adapun pemaknaan endorser 
dimaknai sebagai perantara maupun penghubung antar keduanya agar sinkron dan bersinergis. Media membutuhkan politik dalam rangka menarik minat publik dan politik membutuhkan media dalam upayanya merubah stigmatisasi politik sebagai dunia yang serba culas, keji, dan kejam dengan dipenuhi segala macam intrik politik.

Memahami dimensi selebriti sendiri juga perlu dielaborasi lebih lanjut bahwa selebiriti tidaklah dimaknai sebagai sosok figur semata, tetapi pencitraan yang dilakukan juga di atas panggung hiburan. Selebriti sebagai entitas profesionalisme dimaknai sebagai bentuk figur yang secara benar dan utuh memang menampilkan dirinya sebagai penghibur dan mampu untuk menarik massa secara lebih luas dan massif. Sedangkan selebriti sebagai politisi dimaknai sebagai bentuk manifestasi dari penggunaan komunikasi selebriti sebagai encoder atas bahasa-bahasa politik yang serba konservatif maupun serba rigid diinstrumentalisasikan dalam ragam bahasa hiburan yang mudah dicerna dan dipahami oleh publik.

Adapun terminologi celebrity politician secara literal dapat dipahami sebagai bentuk person yang melalui media mendapatkan popularitas dan presensi kehadiran di ruang publik lebih besar. Dalam hal ini, celebrity politician juga dapat dipahami sebagai kegiatan politik yang dilakukan oleh suatu individu maupun kelompok luas sehingga mampu menarik minat publik. Dari dua pengertian tersebut, mampu menganalisis bahwa pengertian celebrity politician dapat dimaknai sebagai bentuk upayaupaya pemopuleran diri maupun kolektif dengan menggunakan pop culture maupun upaya mengkultusan diri sebagai corong representasi yang mewakili suara mayoritas.

Secara historis, munculnya terminologi celebrity politician sangatlah terkait dengan munculnya fenomena New Labour yang berkembang di Inggris pada era 1970-an. London pada tahun yang sama sedang mengalami gejala perkembangan budaya pop yang berlangsung secara cepat dan dinamis seperti halnya munculnya Britpop, Britrock, Britfashion, dan lain sebagainya. Perkembanganbudaya poptersebutsangatlah dipengaruhi dengan perkembangan televisi modern yang menghegemoni terhadap perkembangan hiburan dan informasi yang didapatkan oleh publik. New Labour sendiri dapat diartikan sebagai bentuk pergerseran orientasi politik dari Partai Buruh pada pertengahan tahun 1990-an sampai pada medio 2010. Adapun transisi tersebut sangatlah dipengaruhi dengan upaya modernisasi politik maupun upaya mengikatkan secara lebih kuat hubungan antara partai dengan konstituennya mereka yakni kaum Buruh (Wheeler, 2013:74).

Secara ideologis, New Labour merupakan manifestasi perkembangan baru partai untuk menyaingi New Rights yang dikembangkan oleh Partai Konservatif. New Rights sendiri yang mengembangkan perspektif ekonomi baru yang berbasiskan pada liberalisme maupun efisiensi pasar, sedangkan dalam politik, dapat diartikan sebagai bentuk kebebasan berekspresi diri. Adapun New Labour sendiri dapat diartikan sebagai anti tesis atas konsepsi yang dibangun oleh New Rights. New Labour dapat diartikan sebagai bentukupaya menghadirkan adanya Berbagai macam usaha untuk memordenisasikan tubuh partai tersebut dilakukan dengan cara menjembatani komunikasi politik secara lebih ekspresif dan tidak lagi dkontekskan dalam hubungan permisif. Hal itu digunakan untuk membedakan dengan Old Labour yang kurang memiliki kepekaaan terhadap isu-isu konstituen karena selama ini lebih terpusat pada era konsolidasi tubuh partai. Dengan mengusung slogan social justice rather than equality, New Labour sendiri banyak mengusung musisi maupun artis yang memiliki keterkaitan isu yang sama seperti halnya Bono U2, Noel Gallagher, Muse, maupun lain sebagainya yang concern terhadap hal tersebut. Maka dari situlah kemudian New Labour berusaha melakukan komodifikasi atas perkembangan musik dan hiburan dengan mengusung budaya populis sebagai corongnya. Para 
selebriti yang tergabung dalam gerakan New Labour itulah yang berperan dalam internalisasi nilai-nilai partai dalam karya seni mereka baik di panggung maupun luar panggung. Adapun selebriti yang tergabung dengan New Labour membuat slogan yang mengatasnamakan Cool Britannia, yaitu bentuk penggambaran Inggris yang baru dengan seimbang dalam segi kesejahteraan masyarakatnya, penegakan HAM, maupun juga sebagai bentuk kebebasan berekspresi. Gerakan Cool Britannia ini sangatlah efektif dalam menjaring suara terutama dari kalangan muda yang terbukti mayoritas prosentase suara di tingkat akar rumpur banyak dikuasai oleh oleh Partai Buruh. Meskipun menggunakan selebriti-selebiriti Implikasinya bisa dilihat kemudian ada pula benchmarking terhadap selebriti ini yang dilakukan oleh pelbagai macama selebriti Partai Buruh seperti halnya Gordon Brown maupun Tony Blair dengan mempopuliskan kehidupan pribadinya yang kemudian dikemas dalam sebuah produk hiburan populer. Maka dari itu, implikasinya adalah kekuatan politik Partai Buruh kemudian mampu meraup suara dalam jangka waktu 10 tahun (Wheeler, 2013: 75). Hal itulah yang kemudian menjadi trendsetter dalam pola kampanye politik kontemporer, yaitu mulai diperkenalkannya model kampanye nonagitatif dan non-dogmatik untuk menggaet akumulasi suara yang tinggi. Kampanye kemudian dikonstruksikan sebagai bentuk kampanye dua arah yang melibatkan adanya partisipasi publik dalam kampanye tersebut maupun juga dalam penekanan diksi kampanye agar lebih menggunakan bahasa populis agar lebih peka dalam menangkap aspirasi politik publik secara lebih holistik.

Kekuatan politician celebrity yang diusung oleh Partai Buruh ini efektif dan efisien dalam melakukan endorsement baik dalam membentuk preferensi politik maupun membentuk pengaruh persuasif politik secara alam bawah sadar. Secara lebih lanjut, pemahaman mengenai celebrity politician sendiri dipahami dalam berbagai tipologi antara lain: pertama, politisi yang terpilih melalui prosentase suara terbanyak (elected politician) melalui jalur latar belakangnya. Politisi yang terlahir dalam konteks ini acap kali disebut sebagai famed non politicos, yaitu orang-orang tenar yang masuk dalam dunia politik. Secara pengetahuan politik, mereka adalah orang awam dari dunia hiburan yang tidak mengetahui dunia politik secara praksis maupun teoritik. Maka yang terjadi kemudian adalah politisi selebriti ini hanya menjadi vote getter saja yang dilakukan oleh partai-partai politik (Street, 2012: 346). Kedua, Kecenderungan menggunakan sosok selebriti dalam kampanye di Indonesia kontemporer menunjukkan gejala pragmatisme dan macetnya sistem kaderisasi dalam tubuh partai. Adapun sosok endorsement sebagaimana yang menjadi lokus dalam menganalisis hubungan selebriti dan politisi sangatlah berbeda jikalau dianalogikan dalam tipologi pertama ini. Sosok endorsement dalam elected politician sendiri (Brubaker, 2011) lebih mengarahkan pada pola ketergantungan partai terhadap selebriti yang menjadi mesin pendulang suaranya (Morin, 2012: 414). Artinya kondisi seperti itulah sangatlah jauh dari konteks ideal bahwa selebriti merupakan sosok endorser bagi seorang kandidasi maupun partai bahwa selebriti ini sebenarnya adalah sosok penguat dan penyokong kekuatan figur bagi kandidat maupun partai. Hal itulah yang menjadikan konteks selebriti politik dalam hal ini menjadi dualism antara selebriti politik maupun politik selebirit yang secara isu dan concern memiliki konteks yang berbeda. Adapun selebriti politik sendiri adalah person yang berangkat dari latar belakang dunia hiburan yang masuk dalam dunia politik praktis, sedangkan politik selebritas adalah pola kampanye politik dengan menggunakan figur populer sebagai voting getter dalam meraih suara.

Letak perbedaannya terletak pada konteks endorsement sebagai upaya pelegitimasian diri sebagai voting getter tersebut. Pada konteks demokrasi elektoral, adanya sosok vote getter merupakan hal urgen dan signifikan dalam meraih suara, Apalagi yang 
dipilih menjadi vote getter tersebut adalah sosok orang terkenal di ruang publik. Hal itulah yang membuat figur tersebut menjadi suatu keharusan dalam setiap kampanye. Akan tetapi, perbedaannyaadalah bagaimana mengkaitkan dengan voting getter dengan konteks endorsement dalam meraih simpati suara. Kedua ranah tersebut sebenarnya merupakan dua rumpun yang berbeda sama sekali. Seorang vote getter tidak akan menjadi seorang endorser yang baik jikalau tidak memiliki komoditas populerisme di mata publik sehingga kurang mampu meyakinkan publik untuk memilih kandidasi yang akan didukung. Sementara itu, seorang endorser tidak akan mampu meyakinkan publik, jikalau tidak memiliki kekuatan persuasif yang begitu kuat dan mengikat. Hal itulah yang menjadikan dua hal tersebut memiliki keterkaitan sama, tetapi memiliki instrumentasi praksis yang berbeda.

Dalam hal ini perlu juga untuk dibedakan antara endorser dengan vote getter dalam memahami konteks darling sebagai selebriti politik. Secara makro sendiri, makna endorser sendiri lebih mengarah pada strategi dalam mengumpulkan dan mengakumulasikan suara. Kandidat yang ingin mendapatkan suara akumulatif lebih harus dapat mengendorse dirinya sebagai sosok yang agamis, dermawan, maupun sosok filantropis lainnya tergantung konteks masyarakatnya. Adapun pola endorsing sendiri dapat dilakukan melalui cara populis-impresif melalui cara pemberian bantuan sosial maupun aksi lainnya. Pencitraan memang menjadi jalan terakhir yang ingin dicapai dalam endorsing tersebut guna mendapatkan simpati. Dalam model kampanye Indonesia sendiri, endorsing berupa penciptaan adanya pencitraan muslim taat, sosok heroik yang suka berderma dan membantu orang, dan lain sebagainya. Intinya adalah penciptaan romantisasi yang kemudian menghasilkan adanya pola endorsing yang dilakukan secara instan dan artifisial.

Adapun yang dimaksudkan dengan pola voting getter dalam hal ini diartikan sebagai upaya menempatkan artis sendiri sebagai agen atau intermediari yang menjembatani antara publik dengan politisi/ partai. Selebriti kemudian diterjemahkan sebagai penarik suara bagi politisi maupun partai melalui popularitasnya. Konteks "aji mumpung" kemudian berlaku dalam membaca darling yang dibentuk melalui voting getter. Baik politisi maupun partai kemudian memanfaatkan ketenaran si selebritis sebagai bagian dari mendompleng keterkenalan. Pada skala besar, terutama pelaksanaan basis kampanye yang dilakukan di kawasan pedesaan. Hadirnya pesohor sendiri bagaikan oase yang menyegarkan untuk sekedar menghilangkan penat kehidupan. Maka jika kita cermati lebih lanjut terutama kawasan industri maupun agraria. Selebriti lebih banyak digunakan dalam kampanye dengan menawarkan berbagai pesan politis yang diselipkan dalam hiburan. Pola komunikatif yang ditunjukkan oleh selebriti sendiri dinilai lebih efektif daripada hanya sekedar mendengarkan pesan agitasi yang normatif dan abstrak.

Maka pembangunan afeksi dan simpati publik yang dilakukan oleh selebriti politik tersebut kemudian ditampilkan dalam bentuk pembangunan political persona. Peran media sangatlah penting dalam melakukan konstruksi atas persona tersebut dengan melakukan pelbagai macam praktik jurnalisme politik. Jurnalisme politik sendiri dalam bahasa komunikasi politik sendiri diartikan sebagai bentuk upaya-upaya jurnalistik yang dilakukan media untuk memperkuat atau justru memperlemah figurisasi suatu person dalam ruang publik. Baik itu dengan cara melakukan bad journalism seperti kampanye hitam maupun sebagainya maupun juga melakukan political framing seperti menjadikannya media darling. Secara lebih mendetail, pembangunan sebuah political persona sendiri sangatlah terkait dengan tiga hal utama, yaitu (1) vocally, (2) iconically, dan (3) kinetic (Corner, 2003:67). Faktor pertama adalah Vocally, yaitu pembangunan persona politik yang dilakukan oleh celebrity politician dalam melakukan politik persuasif sangatlah 
ditekankan bagaimana teknis verbal yang akan disampaikan. Publik sendiri secara terdogmatik melalui pesan-pesan politis yang disampaikan oleh politisi selebriti tersebut jikalau suara yang ditampilkan adalah suara yang ceria maupun periang. Hal itu dikarenakan untuk mengurangi kesan-kesan formalitas yang berada dalam unsur politik. Akan tetapi, premis itu juga tidak mesti 100 persen diterima sebagai pola pakem. Publik sekarang ini cenderung melihat karakteristik calon pemimpin yang sedikir berbicara, tetapi ketika berbicara sendiri sangatlah efektif dan langsung dapat diketahui publik. Oleh karena itulah, secara vocally, teknis penyampaian pesan perlu untuk disampaikan dalam bahasa yang populis.

Kecenderungan yang terjadi dalam kasus kampanye politik baik dalam strata nasional maupun lokal. Banyak terjadi dualisme dalam vocally ini, yaitu politisi dengan selebriti yang menjadi endorser-nya. Politisi secara vocally menampilkan konten bahasa yang serba agitatif sehingga menimbulkan kesan arogan, meskipun substansi yang ditampilkan sendiri sangatalah berkualitas. Adapun selebriti yang menjadi endorser justru menjadi boomerang atas pesan-pesan politis yang disampaikan oleh politisi tersebut. Bahkan dalam kasus selebriti yang maju menjadi politisi sekalipun, meskipun secara vocally sudah mampu melakukan politik persuasif kepada publik. Secara konten, materi yang disampaikan justru malah mengaburkan makna kampanye politis tersebut. Hal itulah yang justru menimbulkan dilema secara vocally dalam upaya menjadi voting getter dikarenakan penyampaian suara dilakukan secara mursal.

Faktor kedua, yaitu iconocally. Pada pembahasan kasus ikon ini memang tidak dibantahkan apabila konteks political persona sangatlah identik dengan sosok ikon tersebut. Hal itu dikarenakan sebagai bentuk simbolisasi atas sebuah entitas politik tertentu. Makin kuat figur seseorang untuk dipersonifikasikan maupun dikonstruksi secara kuat, maka secara peluang akan lebih cepat dalam memperoleh suara dalam ranah publik. Masalah yang timbul kemudian adalah seberapa kuat afiliasi dan afinitas seorang tokoh tersebut dapat menjadi ikon tersebut. Hal itu dikarenakan sering kali ditemukan ikon yang tidak bersimbiosis dengan pola kampanye politik yang dimaksudkan sehingga tidak menemukan endorsement yang dimaksudkan dalam menjadi vote getter. Adapun usaha untuk membangun sebuah ikonik sendiri dapat dilakukan melalui berbagai hal seperti, membangun afiliasi diri terhadap suatu peristiwa tertentu baik secara by design maupun by accident. Akan tetapi, tidak semua klausul tersebut dapat terjadi karena proses menjadi sebuah ikonik juga diperlukan penerimaan masyarakat. Biasanya tokoh masyarakat maupun tokoh populer yang sudah dikenal amat luas akan menciptakan adanya jejaring patronase dengan memanfaatkan legitimasi kharisma yang dimilikinya. Ikon tersebut dengan sendiri akan menjadi celebrity politician dengan kharisma yang dimilikinya, tergantung seberapa besar rekognisi yang diperoleh publik.

Faktor ketiga, yaitu kinetic, yang secara harfiah berarti gerakan. Gesture dan penampilan seorang vote getter yang menjadi endorser memanglah menjadi perhatian penting dalam kampanye politik. Adapun preferensi politik publik kini melihat bahwa kandidasi yang memiliki sifat dinamis, energik, maupun responsif. Terhadap ketiga hal tersebut, sebenarnya dapat dikaitkan dengan upaya pembentukan karakter pemimpin yang melayani dan setia kepada publik. Politisi yang menggunakan teknik selebriti yang serba dinamik belumlah tentu memahami hal tersebut. Bagi yang sudah merasa senior mungkin akan kesulitan dalam mengikuti ritme, tetapi hal itu tidaklah berlaku bagi yang masih muda dan bersemangat untuk dapat meningkatkan daya kinetisnya.

Maka dari itu, jurnalisme politik akan secara mekanis meramu ketiga faktor tersebut apakah seseorang dapat dinobatkan sebagai politician celebrity maupun celebrity politician 
itu sendiri. Tergantung pada peforma persona politik yang selama ini ditampilkan di depan publik itu sendiri. Politisi yang tidak memiliki latar belakang dunia hiburan cenderung untuk masuk dalam ranah politician selebrity, yaitu menggunakan taktik dan strategi politis lainnya, sedangkan selebriti yang berangkat dari latar belakang hiburan akan memasuki kelompok celebrity politician sendiri. Jika digambarkan secara lebih lanjut mengenai persona politik itu sendiri, sebenarnya juga diangkat dari kisah keseharian baik itu skandal, gosip, prestasi, maupun lain sebagainya. Publisitas yang sedemikian biasanya berlaku dalam kasus politisi yang memainkan politik kesehariannya demi mendapat simpati dan empati dari publik. Selebriti pun juga sebenarnya melakukan hal sama, tetapi tentu saja memiliki kadar porsi yang berbeda dengan politisi. Maka dari itu, jika diurai secara lebih lanjut, relasi jurnalisme politik, endorsement, maupun voting getter sebagai berikut ini.

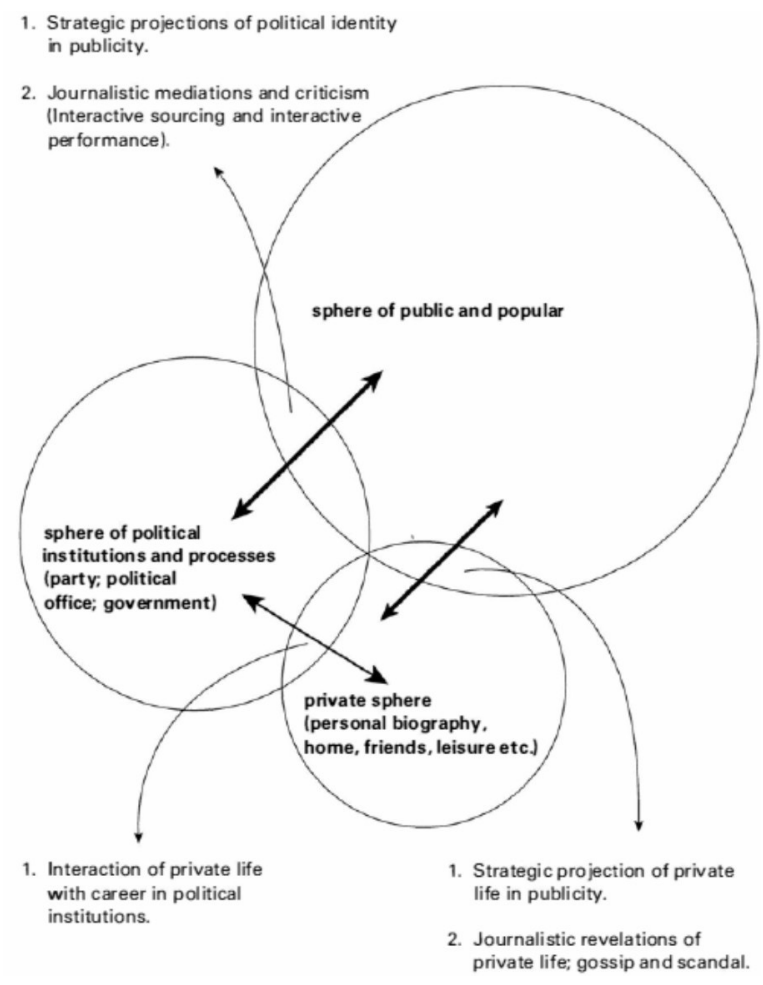

Gambar I

Relasi Jurnalisme Politik, Endorsement, dan Votting Getter dalam Bingkai Sumber : (Corner, 2003: 74)
Jikalau menurut rancang bagun dalam deskripsi table tersebut dapat dianalisis bahwa endorsement maupun voting getter sendiri merupakan bentuk kulminasi dari praktik jurnalisme tersebut yang kemudian diramu dalam ruang publik maupun ruang privat sehingga menciptakan adanya ruang budaya populer. Budaya populer sebagai bentuk komodifikasi ruang privat untuk kemudian menjadi konsumsi publik. Sebenarnya terdapat dua variabel berbeda dalam menganalisis konteks endorser dalam kampanye politik ini. Konteks endorser yang pertama justru malah memarjinalkan sosok kandidasi maupun partai sehingga menimbulkan adanya depolitisasi dalam perhelatan kampanye itu sendiri. Makna idealisme dalam kampanye sendiri justru menjadi nisbi karena tertutup oleh popularitas selebriti tersebut. Sedangkan dalam pengertian kedua, dapat dilihat adanya keseimbangan antara sosok idealisme dengan popularitas yang hendak dicapai dengan mengumpulkan massa banyak. Tipologi pertama ini, sosok celebrity politician yang masuk dalam kategori ini seperti halnya Ronald Reagan, Arnold Schwarzenegger, Clint Eastwood, Joseph Estrada, maupun pelbagai macam sosok selebriti tanah air yang hilir mudik masuk dalam lingkar politik Senayan.

Tipologi kedua adalah celebrity politician yang terlahir dari proses bentuk pengasosian dirinya dengan budaya pop. Politisi yang bukan terlahir dalam dunia hiburan, akan menempuh secara artistik untuk mengidentifikasikan dirinya sebagai bentuk figur humanis dalam keseharian hidupnya. Ada proses ekternalisasi diri yang ditunjukkan oleh beberapa figur politisi agar dapat berkomunikasi dengan publik dan dapat diterima secara meluas oleh publik sehingga terjadi proses pendekatan emosional secara lebih holistik. Praktikpraktik umum yang dijalankan seperti halnya bernyanyi dengan artis, memainkan alat musik, maupun berolahraga. Pola sedemikian ini sebenarnya menjadi efektif dalam menyampaikan pola persuasif 
politiknya agar lebih diterima dan dipahami. Model kampanye demi menimbulkan labelisasi "selebriti" sebenarnya merupakan cara untuk menujukkan kepada publik bahwa kampanye tidaklah selalu dikaitkan dengan upaya menarik suara saja, tetapi menampilkan untold stories yang sifatnya positif dan konstruktif bagi kandidat maupun pemilih. Inti yang disampaikan adalah menampilkan substansi everyday politics bagi para kandidasi untuk menunjukkan sisi humanismenya. Pembahasan mengenai konteks celebrity politic yang berlangsung di Indonesia sendiri dapat dianalisis dalam dua perspektif tersebut darling sebagai bentuk voting getter maupun juga darling sebagai bentuk endorser. Maka dari itu, pembahasan dalam paper ini kemudian akan dibahas dalam dua skope besar.

Pertama, pembahasan mengenai darling sebagai endorser sendiri dapat dimaknai dalam berbagai faktor. (1) Artis tersebut sudah tidak laku lagi di dunia hiburan sehingga mencari sumber nafkah yang sepadan dengan dunia hiburan di dunia politik. (2) Artis tersebut ingin kembali namanya berkibar dan terkenal seperti aktif dulu dengan masuk sebagai legislator DPR sehingga publik bisa tahu sepak terjangnya melalui pemberitaan media. (3) Artis tersebut masuk dunia politik karena mengikuti "idealisme semu" partai politik tersebut agar menjadi bagian dari perubahan bangsa, padahal masih "hijau dalam politik". (4) Artis tersebut masuk dunia politik karena desakan pihak partai politik agar bisa meraih suara sebanyak-banyak dengan memanfaatkan ketenaran artis tersebut. (5) Artis yang benarbenar ingin memperjuangkan aspirasi rakyat berbekal pengalaman kaderisasi politik di partai politik yang cukup lama.

Kedua, pembahasan mengenai darling sebagai voting getter lebih dimaknai sebagai bentuk menghadirkan selebritis sebagai bentuk pengumpul suara. Selebritis yang terkenal dan populis di mata publik menjadi senjata kuat sebagai politisi untuk mendompleng suaranya. Oleh karena itulah, dalam model kampanye seperti ini, model darling sendiri sebenarnya lebih melekat pada sosok selebriti itu sendiri. Selebriti itulah yang nantinya akan mempengaruhi preferensi politik publik untuk memilih figur yang dimaksud. Model kampanye yang sedemikian rupanya telah membiaskan makna kampanye yang sebelumnya mengarah pada model ideologis menjadi lebih lunak. Selebriti inilah yang kemudian berfungsi mengubah pesan ideologi tersebut menjadi pesan populis. Intinya adalah merubah kampanye politik bukan lagi kampanye yang kaku. Akan tetapi, lebih seperti pesta rakyat bagi publik. Pada akhirnya kemudian pemaknaan mengenai negara teater kemudian berlaku dalam model votting getter ini di mana politisi sebagai penyelenggara berusaha menghadirkan sebuah kebesaran untuk dapat dinikmati oleh segenap anggota masyarakat.

Jika dilihat pada kasus Indonesia kontemporer, dua pola ini memang terjadi dalam kasus kampanye di Indonesia. Artis majusebagaipolitisidanpolitisimenggunakan artis sebagai media kampanye. Kedua hal tersebut saling bertemu untuk berkontestasi kursi kuasa. Adapun fenomena artis maju sebagai politisi sendiri dimaknai sebagai bentuk endorser dengan memanfaatkan strateginya sebagai figur terkenal. Fenomena munculnya artis yang masuk ke dalam dunia politik praktis sebenarnya sudah lama. Pelacakannnya dapat dilihat dari munculnya organisasi Parfi yang menjadi saluran korporatisme negara sendiri selama rezim Orde Baru berkuasa. Saat itu, politisi lebih bersuara pasif ketimbang bersuara aktif menjadi subjek aktif. Fenomena munculnya banyaknya artis yang kemudian mulai marak semenjak pemilu legislatif tahun 2004. Tahun 2004 juga ditandai dengan munculnya digitalisasi media dan informasi sehingga pesan dari komunikator kepada komunikan sendiri kemudian menjadi cepat terdiseminasi kepada publik. Hal inilah yang kemudian menandai gerbong masuknya para selebritis kemudian memasuki ranah politik praktis. Pada saat bersamaan, politisi sendiri juga melihat adanya digitalisasi 
media dan informasi sebagai gerbang informasi baru. Pada politik media sendiri berlaku diktum "media adalah juri". Media dapat merekonstruksi dan merekayasa citra dan tampilan seseorang. Politisi yang maju dalam kandidas legislatif maupun eksekutif melihat bahwa media dapat mendongkrak popularitasnya melalui berbagai tampilan yang menarik. Tercatat dalam periode 20042009 sendiri tercatat hampir 19 artis yang melaju menjadi politisi, sedangkan pada 2009-2019 menunjukkan penurunan hanya mencapai 16 orang saja.

Model kampanye yang digunakan artis sebagai strategi sendiri lebih mempopulerkan keterkenalan mereka di media ketimbang harus bersusah payah berkampanye politik. Politisi yang menggunakan darling sebagai strategi sendiri lebih menampilkan strategi pencitraan dalam melakukan kampanye. Pencitraan dapat dilakukan dengan jasa konsultan maupun juga dengan dilakukan dirinya sendiri. Kuncinya adalah menampilkan sosok yang benar-benar merakyat dan menghamba pada kepentingan publik. Pada kasus di Indonesia, sepak terjang artis yang masuk dunia politik yang namanya bergema di telinga masyarakat sangatlh sedikit dibandingkan dengan kiprahnya di dunia hiburan. Sebut saja, Dedi "Miing" Gumelar yang vocal terhadap masalah olahraga dan pendidikan, Nurul Arifin yang vokal terhadap masalah otonomi daerah, Rieke Diah Pitaloka yang peduli masalah buruh, kekerasan perempuan, dan ketimpangan ekonomi, dan Tanthowi Yahya yang peduli terhadap kebijakan politik luar negeri, militer, dan pertahanan Indonesia. Selebihnya di luar keempat artis tersebut, para artis lainnya yang duduk di kursi dewan yang terhormat tidak bergema suaranya dan hanya menjadi anggota dewan yang baik, duduk manis ketika sidang, dan menerima uang ketika rapat selesai. Mereka hanya menjadi anggota pasif yang tidak memanfaatkan keartisan dan keterkenalannya sebagai media penyambung aspirasi rakyat. Yang memalukan justru dari figur artis politik adalah Angelina Sondakh yang terkenal menjadi puteri Indonesia 2004, tetapi akhirnya berkubang dalam sarang korupsi kepartaian.

Masuknya artis ke dalam dunia politik sah-sah saja karena itu merupakan hak politik aktif warga negara untuk ikut serta dalam pemerintahan negara. Akan lebih baik lagi, kalau para artis tersebut juga vokal terhadap masalah masyarakat seperti halnya ketika aktif jadi artis juga sangat vokal dalam dunia hiburan. Jangan hanya menjadi penonton pasif dan menjadi endorser partai dalam meraih suara sebanyak-banyaknya. Adapun jika melihat kecenderungan politisi yang memaikan peran sebagai politic celebrity adalah kerap kali dicap sebagai ajang pencitraan bagi publik. Publik sendiri sebenarnya sudah mampu menilai bahwa kecenderungan tersebut sebagai bentuk pencitraan saja. Hal itulah yang terjadi dalam kontek demokrasi elektoral paska 2009, setiap aksi kepedulian maupun aksi filantropis yang hendak dilakukan oleh politisi dalam menunjukkan sisi celebrity politic tersebut pada dasarnya merupakan sebentuk modus pencitraan di mata publik.

\section{SIMPULAN}

Simpulan dari pembahasan selebriti politik ini adalah upaya untuk menjadi seseorang menjadi bagian dari politik selebriti ataukah selebriti politik sendiri sangatlah tergantung pada konteks endorsement. Hal itu dapat dilacak dari elemen yang mengiringnya entah itu berbasis legitimasi, popularitas, maupun kharisma. Adapun voting getter sendiri pada dasarnya merupakan bentuk kulminasi dari pada endorsement tersebut. Adapun dalam kasus Indonesia, hal tersebut terbendung diskursus pencitraan maupun kapabilitas dalam menilai politic celebrity. Hal itulah menjadi alas an bahwa semangat advokasi yang dilakukan oleh selebriti maupun politisi sangatlah berkurang sekali dibandingkan dengan kasus serupa di luar negeri. Kedepannya, perspektif ini perlu dikembangkan lebih jauh dan mendetail dalam melihat demokrasi elektoral di Indonesia. 


\section{DAFTAR PUSTAKA}

Brubaker, Jennifer. 2011. It doesn't my vote: Third Person Effect of Celebrity Endorsement on College Voters in the 2004 and 2008 Presidential Elections." American Communication Journal. 13(2): 4-21.

Corner, John. 2003. Media and The Restyling of Politic. $2^{\text {nd }}$. London: Sage Publications.

Geertz, Clifford. 1980. The Theatre State in Nineteenth Century Bali. $3^{\text {rd. }}$ New Jersey: Princeton University Press.
Morin, David.et.al. 2012. “Celebrity and politics: Effects of endorser credibility and sex on voter attitudes, perceptions, and behaviors". Social Science Journal 49(1): 413-420.

Street, John. 2012. Do Celebrity Politics and Celebrity Politicians Matter?. British Journal of Politic 14(1): 346-356.

Wheeler, Mark. (2013). Celebrity Politic. $1^{\text {st }}$. Cambridge: Polity Press. 